\title{
Privacy and Social Spaces ${ }^{1}$
}

\section{An Introduction}

\author{
Natália da Silva Perez
}

\author{
TSEG $18(3): 5^{-16}$ \\ DOI: $10.52024 /$ tseg.1 1040
}

\begin{abstract}
In this introductory text to the special issue Regulating Access: Privacy and the Private in Early Modern Dutch Contexts, Natália da Silva Perez argues that privacy can be a productive analytical lens to examine the social history of the Dutch Republic. She starts by providing an overview of theoretical definitions of privacy and of the 'private versus public' dichotomy, highlighting their implications for the study of society. Next, she discusses the modern view of privacy as a legally protected right, explaining that we must adjust expectations when applying the concept to historical examination: in the early modern period, privacy was not yet fully incorporated within a legal framework, although it was a widespread need across different echelons of society. She provides a historical overview of this widespread need for privacy through instances where people attempted to regulate access to their material and immaterial resources. Finally, she describes how the four articles in this special issue contribute to our understanding of the role of privacy in early modern Dutch life.
\end{abstract}

The need to selectively allow and rescind access to oneself, to one's resources, and to information about one's life seems to be widespread among humans. ${ }^{2}$ It is true, as social animals, we do need contact and companionship from our peers and kin. ${ }^{3}$ We thrive by exchanging re-

1 This research was funded by the Danish National Research Foundation (DNRF 138).

2 Michael S. A. Graziano, The spaces between us. A story of neuroscience, evolution, and human nature (New York 2018); Stephen T. Margulis, 'Privacy as a social issue and behavioral concept',Journal of Social Issues 59:2 (2003) 243-261, https://doi.org/10.1111/1540-4560.00o63; Irwin Altman, The environment and social behavior. Privacy, personal space, territory, crowding (Pacific Grove 1975).

3 Patricia S. Churchland, Braintrust. What neuroscience tells us about morality (Princeton 2011 ). 
sources and ideas with each other, and have developed complex systems to obtain and give information. ${ }^{4}$ Yet humans also need to be able to withdraw from contact when they deem it necessary or desirable. ${ }^{5}$ We need to feel safe, to have moments of quiet, to have moments of intimacy with people we choose. To fall asleep we need to feel safe enough, but to rest well it is better to know that we will not be disturbed. Being able to selectively withdraw from social contact gives us the opportunity for much needed mental, emotional, and physical recovery, something that can affect our interpersonal encounters and our functioning in society. ${ }^{6}$ In this special issue of TSEG, we offer four essays discussing how the social organization of spaces in the early modern Dutch context enabled or hindered this ability for people to regulate access to themselves, their communities, and their interests. In other words, our essays investigate the relationship between privacy and social spaces. Taken together, our four case studies illustrate how what we understand as privacy today - this ability to regulate access described above - seems to have been a fulcrum of life in early modern Dutch society.

As a religiously diverse society, the Dutch Republic contended, from its inception, with an ever-latent possibility of religious conflict. The Republic attracted immigrants who found a place to settle there, bringing an added level of cultural and societal diversity that compounded that original potential for religious conflict. A Dutch value of tolerance has been long championed as the enabler of the peaceful coexistence of disparate peoples in the same geographical space, but the idea that tolerance is an exceptional characteristic of the Dutch has also been questioned by those who suspect ulterior motives for the claim. In "Dutch" Religious Tolerance. Celebration and Revision', Benjamin Kaplan discusses how tolerance came to be claimed as part of the Dutch national identity and continues to play an important role in the Dutch imagination:

As a cultural construct, [tolerance] continues to function as a powerful expression of national identity. In that capacity it provides a standard of behaviour against which the Dutch judge their society and government [...] It

\footnotetext{
4 See especially chapter 1: 'Drums that talk'; James Gleick, The information. A history, a theory, a flood (Enhanced Edition) (New York 2011).

5 'Personal space is all about the zone where you keep people out, not the zone where you invite people in. It's an adjustable protective buffer.' Graziano, The spaces between us, 24.

6 Russell G. Foster and Katharina Wulff, 'The rhythm of rest and excess', Nature Reviews Neuroscience 6:5 (2005) 407-414, https://doi.org/10.1038/nrn1670.
} 
also provides a framework for the interpretation of Dutch history. But here the problems begin, for the essentializing of 'Dutch' tolerance has for centuries involved mythologizing, encouraged anachronism, and served partisan causes. In this way it has long obscured our understanding of religious life in the Dutch Republic. Today it does the same, but in a twofold manner: not just by propagating but also by provoking reactions, some of them exaggerated, against such mythologizing, anachronism, and partisanship. ${ }^{7}$

Just as Kaplan suggests, as historians, the contributors to this special issue are indeed skeptical of 'national character as an autonomous, causal force in history. ${ }^{8}$ We believe instead that we might gain valuable insights by analyzing the building blocks of societal values such as tolerance or freedom. In this respect, our contributions seek to investigate how practices of regulating access in day-to-day life - enabled by customs, laws, economic opportunity, and spatial organization might have allowed peaceful coexistence in the Dutch Republic. In other words, we examine the role of strategies of privacy in how Dutch society managed internal and external disparities and conflicts in the wake of the Revolt and the Reformation.

\section{Theorizing privacy and its social implications}

When researchers engage, for analytical purposes, the concept of 'privacy' or the opposition of 'private' and 'public', they often struggle with issues of anachronism or find themselves grappling with divergent theoretical definitions. Nonetheless, exercises in defining and distinguishing are useful: they help to bring nuance to our analyses of the conditions under which the need to regulate access might emerge.

Why do we practice privacy? One answer is that privacy provides a way for us to adjust our social interactions. ${ }^{9}$ According to Stephen T. Margulis, from a psychological perspective, privacy can be social in three different ways. First, privacy relates to interpersonal communication and social interaction, and this sense of social is dominant in dis-

7 Benjamin J. Kaplan, “'Dutch” religious tolerance. Celebration and revision', in: Idem, Reformation and the practice of toleration. Dutch religious history in the early modern era (Leiden 2019), 205-206, https://doi.org/10.1163/9789004353954_o10.

8 Kaplan, 205.

9 Kirsty Hughes, 'A behavioural understanding of privacy and its implications for privacy law', The Modern Law Review 75:5 (2012) 807, https://doi.org/10.1111/j.1468-2230.2012.00925.x. 
cussions of the subject. Second, 'how we experience, understand, react to, and enact privacy are products of our social and cultural development.' In this respect, Margulis means that we learn to practice privacy from observing each other, from our upbringing, much like we learn many other practices from an early age. Third, privacy 'is an attribute not only of individuals but also of groups and, for some theorists, organizations. ${ }^{10}$

It is worth pausing for a moment on the second point noted by Margulis, that is, the idea that privacy is social in the sense that it is learned from social interactions. This aspect comes into sharp focus when recalling Norbert Elias's comments on the different sensibilities about privacy that he noted between what he called the 'courtois world' of medieval times and his understanding of what is acceptable behaviour in modern societies:

Their affects were conditioned to forms of relationship and conduct which, by today's standard of conditioning, are embarrassing or at least unattractive. What was lacking in this courtois world, or at least had not been developed to the same degree, was the invisible wall of affects which seems now to rise between one human body and another, repelling and separating, the wall which is often perceptible today at the mere approach of something that has been in contact with the mouth or hands of someone else, and which manifests itself as embarrassment at the mere sight of many bodily functions of others, and often at their mere mention, or as a feeling of shame when one's own functions are exposed to the gaze of others, and by no means only then. ${ }^{11}$

Regarding what is meant by 'private' versus 'public,' Jeff Weintraub offers two basic orientations. In the first, private means 'what is hidden or withdrawn' and public means 'what is open, revealed, or accessible.' In the second, private means 'what is individual, or pertains only to an individual' and public means 'what is collective, or affects the interests of a collectivity of individuals.' Furthermore, Weintraub notes that these two basic distinctions are the foundation of four important and common ways in which the dichotomy private/public is used to describe 'kinds of human action - and, beyond that, the different realms

10 Margulis, 'Privacy as a social issue and behavioral concept', 248-249.

11 Norbert Elias, The civilizing process. Sociogenetic and psychogenetic investigations, vol. 1 (Hoboken 2000) 6o. 
of social life, or the different physical and social spaces, in which [these actions] occur.' His list, he explains, is not meant as exhaustive, but nonetheless it is a useful guide for us to understand theoretical debates about the topic:

- One way in which the dichotomy is used is notable when 'state administration' is referred to as public and 'market economy' is referred to as private;

- Another one is influenced by a 'republican-virtue (and classical) approach' where public is used to refer to ideas of 'political community and citizenship' as distinct from the above mentioned state administration and market economy;

- Another way posits 'the family' as the private and 'the larger economic and political order' as the public;

- And finally, the public is that which refers to 'a sphere of fluid and polymorphous sociability' where 'cultural and dramatic conventions' influence exchanges between individuals. ${ }^{12}$

In The Structural Transformation of the Public Sphere, Jürgen Habermas's employment of 'public' reflects ideas contained in the second as well as in the last items in the list above. The 'public sphere' is posited as a dimension of society where members have the opportunity to come together - literally or metaphorically - to exchange ideas, opinions, and arguments about topics related to their living together in a shared polity and are, through this exchange, capable of influencing state authorities. The 'private sphere', on the other hand, is a dimension where individuals can be unencumbered by external influence or coercion from state administration. ${ }^{13}$ We can see that Habermas's use of the term public, at least as employed in The Structural Transformation of the Public Sphere, resonates both with ideas of 'political community and citizenship' as well as with the sense of a 'fluid and polymorphous sociability', noted by Weintraub. Indeed, speaking about Ancien Regime France, Dena Goldman observes that it was thanks to 'institutions of sociability that private individuals gathered to use their reason and form civil society.' ${ }^{14}$

12 Jeff Weintraub, 'The theory and politics of the public/private distinction', in: Jeff Weintraub and Krishan Kumar (eds.), Public and private in thought and practice. Perspectives on a grand dichotomy (Chicago 1997) 5-7.

13 Jürgen Habermas, The structural transformation of the public sphere. An inquiry into a category of bourgeois society, trans. Thomas Burger, reprinted (Cambridge 2008).

14 Dena Goodman, 'Public sphere and private life. Toward a synthesis of current historiographical approaches to the Old Regime', History and Theory 31:1 (1992) 7, https://doi.org/10.2307/2505605. 
Both in a historical as well as a theoretical perspective, therefore, the dichotomy private/public seems to be polysemous.

In The Value of Privacy, Beata Roessler's exercise of defining and nuancing what is meant by privacy resonates with Weintraub's efforts about the dichotomy private/public. Roessler notes two commonly used meanings of privacy: one centres that which pertains to a person, as a physical and moral being that exists in the world. To explain this sense of privacy, she posits concentric, layered areas radiating out from the individual's bodily presence. The first layer external to the individual opens towards their family and intimate relations, the next layer is society, and finally the next is the state under which this individual lives. This first model tends to use metaphors associated with space. Roessler also notes a second common meaning for privacy, this time not centred on the entity of the person, but rather focused on describing 'a protected sphere or dimension of action and responsibility, where individuals can act in a way that is independent of decisions and influences from the public realm of state institutions and society at large.' This second meaning is not easily described in terms of space but, rather, 'dimensions of action and responsibility... interest and concern. ${ }^{15}$

Whether in modern or historical perspective, examining the role of space is a crucial part of the analysis of social interactions involved in regulating access to material resources (such as someone's own body or their personal belongings) or immaterial resources (as in the case of information about someone or about a transaction). As Lasse Suonperä Liebst and Sam Griffiths explain, pointing to the work of Émile Durkheim and of Bill Hillier and Julienne Hanson, 'spatio-morphological arrangements enable the construction of social relations across space. ${ }^{16}$ For them, we must pay attention to 'the productive role of society's material organization in generating, constraining, and assembling social relations.' Adapting Liebst's and Griffiths's insights for the purposes of a historical inquiry into privacy, our special issue endeavours to do precisely this, to analyze the relationship of space and privacy for social interactions in varied Dutch contexts. Keeping the psychological, theoretical, and political nuances discussed above in mind, we can start to see that a simple opposition between private and public is unlikely to be a helpful analytical strategy.

15 Beate Roessler, The value of privacy (Cambridge 2005) 5-6.

16 Lasse Suonperä Liebst and Sam Griffiths, 'Space syntax theory and Durkheim's social morphology. A reassessment', Distinktion:Journal of Social Theory 21:2 (2020) 216, https://doi.org/10.1080/160091 oX.2019.1641121. 


\section{A right to privacy}

We now tend to see privacy as a protected right. However, it was only in the twentieth century - with the aftermath of the Holocaust bringing focus to the need to protect individuals - that examples of values related to privacy started to be codified as law. The Universal Declaration of Human Rights was adopted in 1948 with article 12 stating that 'No one shall be subjected to arbitrary interference with his privacy, family, home or correspondence, nor to attacks upon his honour and reputation. Everyone has the right to the protection of the law against such interference or attacks.' Articles 18 through 21 deal with specific rights that, upon close analysis, are undergirded by privacy, such as 'freedom of thought, conscience and religion,' 'freedom of opinion and expression,' 'freedom of peaceful assembly and association,' 'the right to take part in the government' and to the 'secret vote or... equivalent free voting procedures. ${ }^{17}$ In Europe, efforts started with the Council of Europe's European Convention on Human Rights in 1950, and culminated with the European Charter of Fundamental Rights, which first appeared in 2000 and obtained official recognition in 2007. Its article 7 stipulates that 'Everyone has the right to respect for his or her private and family life, home and communications.'.18

In the twenty-first century, personal information came to the forefront. In the high-tech sector, hungry as it is for our data in order to infer our buying behaviours and try to influence us, concerns over how our personal information is used tend to dominate discussions about privacy. ${ }^{19}$ Notably, it is in article 8 of the European Charter of Fundamental Rights that we find 'Protection of personal data,' detailing that 'everyone has the right to the protection of personal data concerning him or her;' 'such data must be processed fairly for specified purposes and on the basis of the consent of the person concerned or some other legitimate basis laid down by law. Everyone has the right of access to data which has been collected concerning him or her, and the right to have it rectified', and 'compliance with these rules shall be subject to control by an independent authority. ${ }^{20}$

17 'Universal Declaration of Human Rights', 6 October 2015, https://www.un.org/en/universaldeclaration-human-rights/.

18 'Charter of Fundamental Rights of the European Union', 26 October 2012, https://eur-lex.europa. eu/legal-content/EN/TXT/HTML/?uri=CELEX:12012P/TXT\&from=EN.

19 Shoshana Zuboff, The age of surveillance capitalism. The fight for a human future at the new frontier of power (London 2019).

20 'Charter of Fundamental Rights of the European Union'. 
When we study privacy in the past, however, we have to adjust our expectations, because although the need for privacy has been similar across the ages, the strategies to achieve it have been very different. Despite it being a need, privacy has only recently started to enjoy this status of a legally protected right. For many centuries, it has been a privilege accessible to those powerful enough to defend it, by force if needed. In historical societies, where social hierarchies were much starker than today, receiving respect was often a privilege for those higher in the social echelons. In this context, it is worthwhile to notice that the article 7 of the EU charter emphasizes the universal entitlement to respect: Everyone has the right to respect for his or her private and family life, home, and communications.

\section{Regulating access: a historical perspective}

Historically, secrecy and concealment have served as strategies for regulating access to important or desired information in contexts of power differential. The work of Daniel Jütte, in The Age of Secrecy, shows how these strategies played out between Jews and Christians in the realm of learned practices. ${ }^{21}$ Londa Schiebinger in Secret Cures of Slaves, in turn, provides a nuanced account of the interplay between concealment of knowledge, protection of information, and socio-political power between, on the one hand, European seekers of novel medicinal plants in the American continent and, on the other hand, the Indigenous Americans and Africans who held the knowledge about such plants' curative capabilities. ${ }^{22}$ Shared between Jütte's and Schiebinger's accounts is the insight that secret knowledge was often perceived as a source of power in the early modern period and was jealously sought after by parties that wished to get an edge over their competitors.

Moving away from questions about information, we come now to historical instances of regulating access to one's physical body, as well as the consequences of failing to do so. Of relevance here is, for example, the book The Burgher and the Whore: Prostitution in Early Modern Amsterdam, where Lotte van de Pol discusses relations between sex

21 Daniel Jütte, The age of secrecy.Jews, Christians, and the economy of secrets, 1400-1800 (New Haven 2015).

22 Londa L. Schiebinger, Secret cures of slaves. People, plants, and medicine in the eighteenth-century Atlantic world (Stanford 2017). 
workers and other citizens in the Amsterdam urban context. ${ }^{23}$ Secrecy, concealment, and deception become relevant, nonetheless, in The Tradition of Female Transvestism in Early Modern Europe, by Van de Pol and Rudolf Dekker, when they discuss women who passed as men while working on the Dutch East India Companies' ships. Their study shows that information about the body cannot be easily disentangled from the body itself in historical analysis, an insight germane to privacy studies.

Lena Cowen Orlin, in Locating Privacy in Tudor London, demonstrates how the type of privacy that we associate with solitude could be improvised by creatively repurposing a domestic space like the closet. Closets were, according to Orlin, 'added in great numbers in the early modern period and that has long been uniquely associated with the history of privacy.' Orlin argues, though, that using the closet as a space of solitude for privacy purposes was likely an improvisation, one of the 'unanticipated effects of spaces built for other purposes.' Just as so many parents, juggling work and family during the COVID-19 pandemic, found some quiet for a video call inside a closet, an early occupant of Boughton Monchelsea Place in Kent might have sought some quiet in the same way, and in a closet, 'this room meant for objects, [...] perhaps discovered the subjectivity that we associate with authorship.'.24

David Vincent's first chapter in Privacy, a Short History resonates with the discussion above about the view of privacy as a codified right. In the chapter aptly titled 'Privacy before Privacy 1300-1650,' Vincent provides evidence that the need to regulate access to one's domestic space has long been a reality in densely populated urban spaces such as London, as evinced by cases in the London Assize of Nuisance in the fourteenth century. Vincent highlights common features of the cases brought there about privacy: first, there was 'a critical distinction between the inside and the outside of the dwelling place'; second, 'the conflicts were for the most part between two social groups'; third, usually the conflicts 'represented a failure of informal negotiation' between the groups involved; and fourth, 'the conflicts involved, in some way, the transmission of information.' Vincent shows that, when at home, 'the occupants' enjoyment of an enclosed universe of communication should not be compromised by sight or by sound' from the neighbours, and when it was compromised, occupants could complain to the authorities. ${ }^{25}$

23 Lotte van de Pol, The burgher and the whore. Prostitution in early modern Amsterdam (Oxford 2011).

24 Lena Cowen Orlin, Locating privacy in Tudor London (Oxford 2008), 8, 286-326.

25 David Vincent, 'Privacy before privacy 1300-1650', in: Idem, Privacy: A short history (Oxford 2016), http://ebookcentral.proquest.com/lib/kbdk/detail.action?docID=4432249. 
As we can see, the relationship of privacy with the ability to regulate access can be historically analyzed by focusing on negotiations that happened in the thresholds of power. Mette Birkedal Bruun proposes an analytical strategy based on heuristic zones of privacy that can be useful here. She explains that these heuristic zones are reminiscent of Roessler's concentric model, with 'layers of personal/bodily intimacy, family, society and the state as the public realm.' Bruun incorporates some adjustments to the model in order to adapt it to the analysis of life in the early modern period. The soul is considered separately from the body and the chamber separately from the home for the purposes of analysis. Moreover, the circles of privacy are no longer concentric, with each outer circle contained in the inner one. Rather, they are arranged as a fanned-out diagram, with some of their areas falling outside of the area of the next bigger circle, thus facilitating the analysis of 'thresholds and overlaps.'. ${ }^{26}$

Bruun suggests that historians of privacy might benefit from these heuristic zones as tools for formulating questions adapted to the domain of early modern research. These heuristic zones help historians to zoom in on different aspects of historical sources that can be useful to analyze as regards privacy, for example, by enabling examination of the negotiations that happened when entities that operated at different scales met and needed to compete for access to something: themselves, a needed space, a resource, a claim to an idea, and so on. An example can help clarify here. Consider an individual who enters a religious temple during a religious ceremony. We can analyze the practical use of that space from the point of view of this individual, but we can also consider the point of view of the religious community whose building is being entered. What are the community values? What are the individual's intentions? Is this person a known member? Are they perhaps an outsider who came uninvited? Or did they come by invitation of a prestigious community member? We can also zoom out our analytical lenses to the administrative level of the city where the temple stands: what are its laws governing access to religious temples? Is this temple clandestine or authorized? In this particular situation, the level of analysis would require us to take into account the different values that might be in competition (see Silva Perez and Kristensen, this volume, for further discussion).

26 Mette Birkedal Bruun, 'Towards an approach to early modern privacy. The retirement of the great Condé,' in: M. Green, L. Nørgaard, and M.B. Bruun (eds.), Early modern privacy. Sources and approaches (Leiden 2021) 12-6o. 
In a time where in-person communication and contact had a prevalent role in people's social lives, the shared physical space was often the first medium where ideas were exchanged and opinions were formed, shaped, and transformed. Physical spaces where people met to talk, to work, to worship, all presented occasions for ideas to flow from one person to another, and perhaps come back altered, reshaped, reimagined. ${ }^{27}$ Even so, the organization of spaces also allowed individuals to take respite from these exchanges, permitting moments where they could step away from debate, from overt and even implicit conflict. As we will see from the examples in this special issue, this ability to regulate access to oneself and to one's belongings depended heavily on the ability of a person to regulate the space they occupied.

\section{This Special Issue}

In 'Spaces of Privacy in Early Modern Dutch Egodocuments,' Michaël Green focuses on texts written by members of the elite and of the middling echelons of Dutch society. He starts by discussing Simon Stevin's ideas on the idealized family home and their contribution to the discourse on privacy in the Dutch context. Green notes that the writers he analyzes do not use a particular word to refer to the abstract concept of privacy, but nonetheless he finds traces of their insights into the topic. Focusing on how these writers wrote about their personal and domestic spaces, Green interprets their words as hints about how they understood the relationship of their feelings and ideas to the spatial organization of their homes.

In 'An Extraterritorial Privacy Zone? Dutch Protestants and their Embassy Chapel in Early Modern Portugal,' Tom-Eric Krijger examines Dutch-Portuguese diplomatic relations in the wake of the Reformations. The Treaty of Truce and Commerce emerges from his discussion as an important precursor of the principle of extraterritoriality in international diplomacy. As spaces for religious practices, embassy chapels were protected through diplomatic agreements, but since they were physically located in a different country, they were subjected to the scrutiny of a different government following a different set of cultural assumptions about privacy for spaces of worship. Power and sovereignty become apparent 
as a means to obtain that ability to regulate access to that space of religious practice. As will become evident from Krijger's nuanced discussion, the Portuguese and the Dutch had different ideas of what private meant in the context of religious worship.

In 'Gender, Space, and Religious Privacy in Amsterdam,' Natália da Silva Perez and Peter Thule Kristensen focus on that city in the seventeenth century, and discuss concealed and visible places of worship for two unsanctioned religious communities. Silva Perez and Kristensen zoom in on the interplay between gender and the organization of religious spaces. One of the communities discussed in the article is the Catholic Beguines, who lost their visible courtyard church as a result of the Alteratie but later managed to build the schuilkerk Church of Saint John and Saint Ursula. The other is the Iberian Jewish community referred to by its members as the Portuguese Nation. When they first arrived in Amsterdam, the members of this community complied with the mandate of private worship for religions other than the Dutch Reformed Church, but slowly, by relying on strategies of respectability and discretion, they managed to build more and more spacious and elegant synagogues for their religious community, culminating with the sumptuous Esnoga. As will be clear from the article, gender intersected with cultural and religious values to shape the spaces of worship built under the restrictions of seventeenth-century Amsterdam.

In 'Spaces on Ships: Secrecy and Privacy in the Dutch East India Companies,' Djoeke van Netten discusses practices of regulating access in the context of VOC ships. Given the very restricted space available for the many people who lived aboard a ship, hierarchies of privacy became starker there than on land, because there was simply not enough room for everybody to claim their own personal space. Van Netten also discusses Dutch efforts, first, to obtain Portuguese navigational secreten in order to get advantage in their trade efforts in the Pacific, and then, subsequently, to protect these secrets in order to maintain their informational advantage. She finishes with a discussion of theoretical approaches to secrecy and privacy, highlighting the importance of putting both scholarly approaches in conversation. 